\title{
ПРОЕКТУВАННЯ ВЕЛОСИПЕДНОЇ ІНФРАСТРУКТУРИ В РЕКРЕАЦІЙНИХ ЗОНАХ МІСТА
}

\section{DESIGN OF BICYCLE INFRASTRUCTURE IN THE RECREATIONAL AREAS OF THE CITY}

\author{
Зигун А.Ю., к.т.н., доцент, Клєпко А.В., студентка (Національний \\ університет «Полтавська політехніка імені Юрія Кондратюка», \\ Полтава)
}

\author{
Zyhun A. Yu., PhD, Associate Professor, Kliepko A.V., student \\ (National University «Yuri Kondratyuk Poltava Polytechnic», Poltava)
}

На сучасному етапі розвитку міст велосипедний транспорт для більшості розвинених краӥн є важливим видом внутрішнього транспорту. Велосипедні поїзки використовуються у повсякденному житті як транспортний засіб для комунікаційних та рекреаційних цілей. Для популяризації $i$ стимулювання використання велосипедів у межах рекреачійних зон, необхідне створення велосипедної інфраструктури: велосипедних смуг на дорогах, велодоріжок, спеціальних велосипедних трас, велосипедної навігації, а також велосипедних стоянок, місиь відпочинку, пунктів прокату та систем ремонту.

At the present stage of urban development in most developed countries, bicycle transport is an important mode of internal transport. It signifies an important role in ensuring social development and road transport replacement in the process of population movement within cities and suburban travel. Cycling is used in everyday life as a vehicle for communication and recreational purposes. Bicycle traffic is an environmentally friendly, comfortable, healthy mode of transport that has a number of advantages over other modes of transportation.

Bicycle infrastructure should be integrated into the urban space and all its functional areas. This means that it is necessary to somehow combine the opposite needs of different categories of citizens and ensure an appropriate level of the urban environment. Conditions must be created to ensure safety, connectivity, straightforwardness, attractiveness and convenience in organizing bicycle infrastructure facilities.

The bicycle infrastructure in the recreational areas of the city provides marked (indicated by pointers and signs) routes for long or short trips and tourist themed routes. Such routes are usually a set of nodes connected by separate tracks. This gives cyclists the freedom to choose directly: everyone can create their own route within the network. The main advantage of such networks is that they allow you to independently explore a particular area. For recreational purposes, the attractiveness of the proposed routes and the surrounding area is much more important than the ability to reach the destination by the shortest route.

It is necessary to create a bicycle infrastructure: bicycle lanes on roads, bicycle 
paths, special bicycle routes, bicycle navigation, as well as bicycle parking lots, resting places, rental points and repair systems to popularize and stimulate the use of bicycles within recreational areas.

Ключові слова: велосипедна інфраструктура, рекреачійна зона, велосипедна навігаџія, веломаршрути.

Keywords:bicycle infrastructure, recreation area, bicycle navigation, bicycle routes.

\section{Аналіз останніх досліджень та постановка задачі}

В останні десятиліття велосипедний транспорт у містах переживає бурхливий інноваційний етап свого розвитку. Успіх криється в позитивних синергетичних ефектах для довкілля: від боротьби з транспортними та екологічними проблемами до поліпшення здоров'я людей, економічного розвитку та оздоровлення соціально-культурного стану суспільства.

Форми велосипедного руху, прокладені по вулицях міста і поза ними, утворюють єдину цілісну мережу веломаршрутів, що забезпечує унітарні та рекреаційні поїздки велосипедом в межах міста та на околицях. Відповідно до містобудівних і транспортних умов проектування, правил організації дорожнього руху визначається форма велосипедного руху. Технічні параметри кожної велосипедної доріжки визначаються проектною організацією індивідуально для кожного випадку, враховуючи місцеві умови та вимоги державних стандартів.

Наявна нормативно-правова база в Україні, яка регламентує планування або використання велосипедної інфраструктури, обмежується Правилами дорожнього руху, Державними будівельними нормами $[1,2]$ та документами, що можуть бути прийняті органами місцевого самоврядування, а саме, правила благоустрою територій, концепції, міські цільові програми [3].

Рекомендації до створення велоінфраструктури відображено в європейських програмах NACTO Urban Bikeway Design Guide, PRESTO Cycling Policy Guide-General Framewo, Recommendations for the organization of bicycle traffic ERA [4-6].

Дослідженням велосипедної інфраструктури активно займаються Токміленко О.С., Литвиненко Т. П., Гасенко Л. В., Шевченко Л.С., Буравченко С. Г., Чернишова О.С. [7-11]

Існує суттєва різниця в підходах до проектування в забудованій та незабудованій території, а також залежить від функціонального призначення маршруту.

Велосипедну інфраструктуру потрібно інтегрувати у суспільний простір, якого в більшості випадків й так вже не вистачає. Це означає, що необхідно поєднувати протилежні потреби різних категорій городян і при цьому забезпечувати належний рівень міського середовища. Неврахування 
категорії користувачів і цілей пересування при створенні велосипедної інфраструктури може призвести до того, що вона буде неефективно використовуватися.

Проаналізувавши вітчизняні та закордонні джерела, нормативну літературу 3 питань проектування велосипедної інфраструктури, ми зробили висновок, що значна увага приділяється питанням розвитку утилітарних велосипедних маршрутів для щоденних транспортних потреб. Проте майже не розглядаються інфраструктурні рішення 3 метою покращення безпеки і комфорту велосипедистів в рекреаційних зонах міста.

\section{Виклад основного матеріалу}

Для проектування велодоріжок рекреаційного призначення потрібен інший підхід, ніж облаштування утилітарних транспортних. Насамперед, такі доріжки мають бути привабливими для прогулянок і мальовничими. Вони можуть з'єднуватися з житловою забудовою або транспортними вузлами, але розташовуються переважно у зелених рекреаційних зонах на відстані з іншою міською інфраструктурою.

Традиційно під рекреаційними маршрутами розуміють промарковані (позначені покажчиками та знаками) маршрути для тривалих поїздок та туристичні тематичні маршрути. Їх зазвичай представляють як набір вузлів, з'єднаних між собою окремими доріжками. Це надає велосипедистам свободу вибору напряму: кожен може прокласти в межах мережі свій маршрут. Основна перевага таких мереж полягає в тому, що вони дають можливість самостійно дослідити ту чи іншу місцевість.

Залежно від значення велосполучення у мережі, для велосипедного руху висуваються різні вимоги стосовно прокладання у плані, розділення 3 пішоходами та іншого додаткового облаштування (наприклад, покажчики, освітлення). Особливо для велоруху з рекреаційною метою є широке поле застосування, що не робить доцільною стандартизацію елементів облаштування. На основних сполученнях велоруху до важливих рекреаційних пунктів призначення у певні дні інтенсивність руху велотранспорту може значно зростати, це вимагає встановлення конструктивних елементів для розмежування пішохідного та велосипедного руху. 3 іншого боку, доцільними можуть бути вужчі доріжки за мінімальним стандартом для віддалених зон відпочинку та 3 метою меншого втручання у природу (рис.1).

Виходячи $з$ потреб користувачів велосипедного транспорту, можливо визначити п'ять основних вимог, що сприяють розвитку велосипедного руху. Сенс цих вимог у тому, що чим більшій кількості відповідає інфраструктура, тим більше вона спонукає людей використовувати велосипеди не лише в утилітарних цілях, а й з рекреаційною метою. 

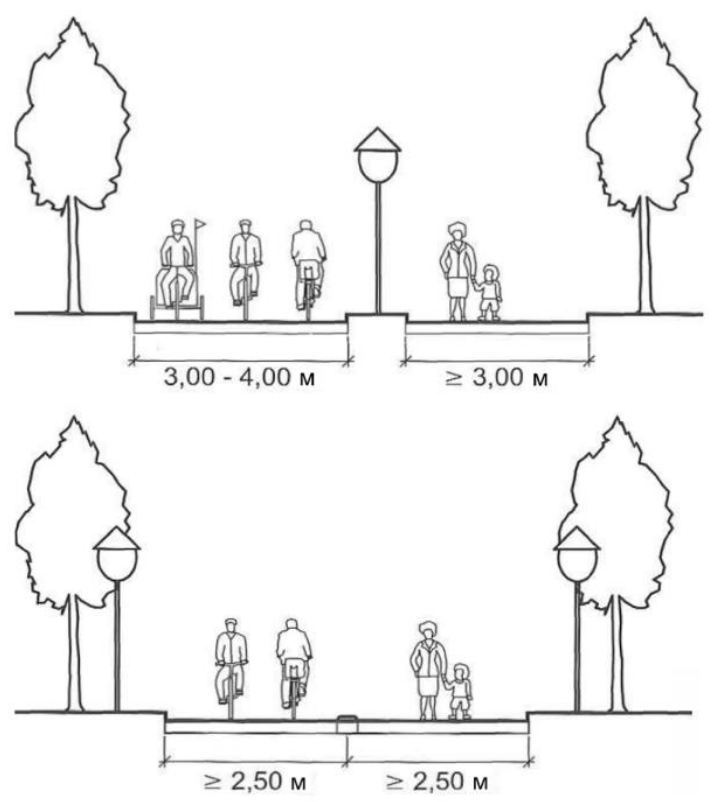

Рис 1. Приклади поперечних перерізів для велодоріжок та пішохідних доріжок, що розташовані в рекреаційних зонах міста

Ці вимоги можливо використовувати як критерії для оцінки якості та виявлення слабких місць існуючої інфраструктури.

1. Безпека.

Виконанню цієї вимоги повинна приділятися найбільша увага.

Для забезпечення поєднання велосипедного, пішохідного та автомобільного трафіку існує три основні напрями - зменшення інтенсивності руху, зниження швидкості руху та відокремлення учасників pyxy.

2. Прямолінійність.

Сполучення початкової та конечної точки призначення найбільш прямим i коротким шляхом. Необхідно мінімізувати відхилення та можливі затримки. Це робить велосипед дуже конкурентоспроможним видом транспорту на невеликих дистанціях, оскільки час поїздки в більшості випадків буде меншим, ніж при використанні автомобіля.

3. Зв'язність.

Відсутність розривів в мережі 3 вихідної точки до пункту призначення, тобто велосипедна мережа, що охоплює всі райони міста.

4. Привабливість.

Це питання інтеграції велосипедної інфраструктури в міське 
середовище, відчуття i сприйняття, які виникають у людей при довготривалому чи короткочасному використанні велосипедів.

\section{5. Зручність.}

Рух має вимагати мінімальних фізичних та розумових зусиль. Слід уникати проектних рішень, які потребують постійної зміни швидкості руху. Велика кількість перехресть зумовлює необхідність постійно зупинятися і починати рух спочатку. Неякісний або невідповідний тип покриття, наявність ям, тріщин та інших нерівностей призводять до необхідності зниження швидкості руху. Це робить їзду на велосипеді складнішим завданням, що потребує більшої концентрації та зусиль.

В залежності від призначення велосипедні маршрути відрізняються за пріоритетністю зазначених вимог. Для щоденних ділових поїздок важливо, щоб маршрути дозволяли їхати швидко і без зусиль, навіть якщо вони пролягають через непривабливу місцевість. Для рекреаційних маршрутів дуже важлива привабливість, а їх «петляння», необхідність об'їздів тощо, навпаки, не $\epsilon$ помітною проблемою.

До супутніх елементів проектування велосипедної інфраструктури належать: майданчики тривалого та короткочасного зберігання велосипедів, станції велопрокату, пересадочні та накопичувальні пункти для велосипедистів, спеціальні велосипедні вказівники та інше.

Велосипедні знаки та покажчики є основним елементом кожної мережі велосипедного руху. Це допомагає зробити існуючі велосипедні мережі більш помітними для громадськості та безпечно, зручно направляти користувачів. За допомогою покажчиків призначення можливо надати велосипедистам важливу інформацію про пункти призначення та характеристики маршруту. На всіх відгалуженнях маршрутів і перехрестях завжди повинні бути встановлені знаки призначення.

Для деталізації загальної системи веломаршрутів із виділенням маршруту на якому знаходиться людина та вказує точку ії перебування встановлюються інформаційні щити уздовж рекреаційних велосипедних маршрутів (рис 2). Щит повинен розміщуватися так, щоб не заважати проїзду велосипедиста, а його краї повинні перебувати за межами, однак поруч із простором для руху велотранспорту.

Проміжні покажчики на маршруті гарантують, що маршрут залишається чітко впізнаваним подалі від точок прийняття рішення (розміщення інформаційних щитів). Проміжні вказівники слід використовувати при розгалуженні маршрутів (рис.3).

Система навігації повинна відповідати критеріям:

- $\quad$ легко читатися, особливо велосипедистами на ходу, а також людьми із вадами зору;

- $\quad$ використовувати загальнозрозумілу систему символів, знаків та інфографіки; 
- вандалостійкість, стійкість до погодних умов та легкість ремонту або відновлення;

- $\quad$ не заважати проїзду та оглядовості велосипедистам та іншим учасникам руху.

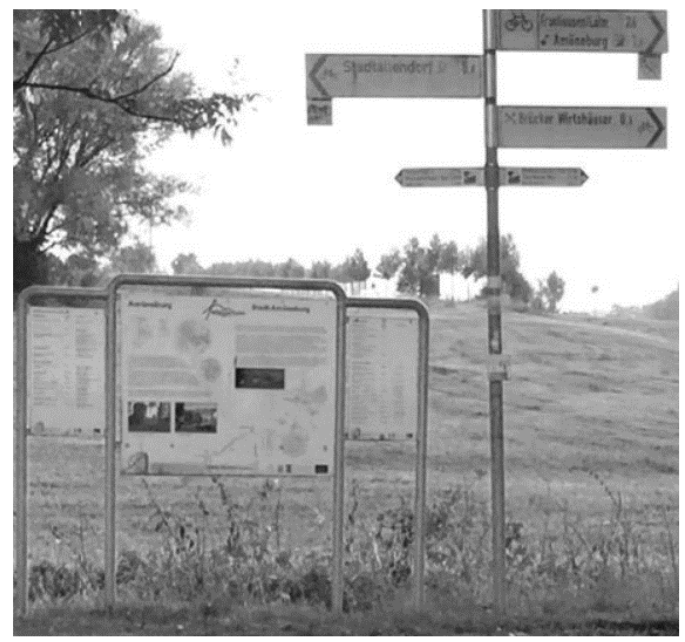

Рис 2. Приклади застосування інформаційного щита та знаків перехрестя зі стрілочними вказівниками
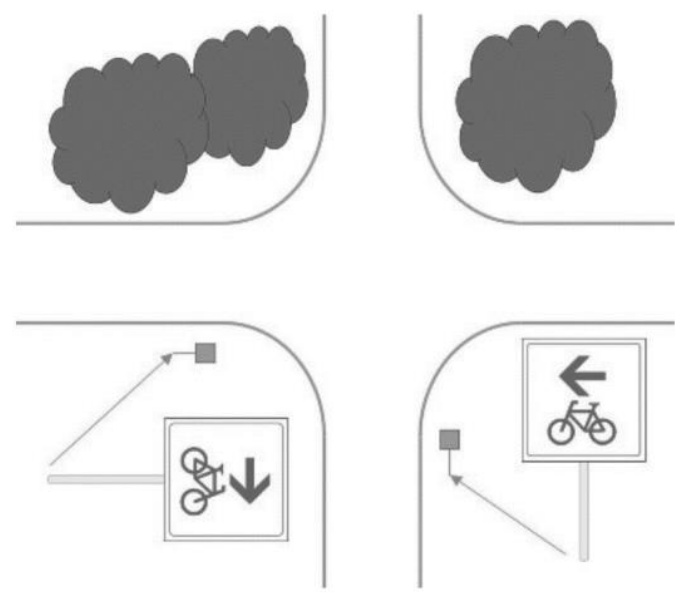

Рис 3. Приклади застосування проміжного покажчика 
Користувачі велосипедного транспорту потребують додаткових зручностей для надійного зберігання велосипедів. Ефективна система велосипедного паркування повинна відповідати вимогам з урахуванням різних потреб користувачів, а саме:

- $\quad$ розрізнення короткотривалого паркування та довготривалого зберігання велосипедів. Велосипедисти повинні мати вибір між різними видами стоянок залежно від їхніх потреб та тривалості перебування;

- рівень попиту залежно від різних міських умов та розташування у структурі міста;

- $\quad$ проблеми зі зберіганням велосипедів у міському житлі;

- $\quad$ вибір між різними видами паркувального обладнання.

Висновок. У межах рекреаційних зон велосипедна інфраструктура повинна включати не тільки велосипедні доріжки, а й стоянки довготривалого та короткочасного зберігання велосипедів, пункти прокату велосипедів та засобів індивідуальної мобільності, засоби навігації, зони обслуговування та ремонту. Стоянки та оглядові майданчики для велосипедів необхідно передбачати в різних функціональних зонах території на рівновіддаленій відстані між собою.

\section{References}

1. DBN V.2.3.-5:2018 Vulytsi ta dorohy naselenykh punktiv. K.: Ministerstvo rehionalnoho rozvytku, budivnytstva ta zhytlovo-komunalnoho hospodarstva Ukrainy, 2018. $61 \mathrm{p}$.

2. DBN B.2.2-12:2018 Planuvannia i zabudova terytorii. K.: Minrehion Ukrainy, 2018. $187 \mathrm{p}$.

3. Pro zatverdzhennia Kontseptsii rozvytku velosypednoi infrastruktury mista Poltava 2020-2024: Rishennia Poltavskoi miskoi rady vid 10.07.2020 [Digital source] / Ofitsiinyi sait instytutu rozvytku mist. https://irm.pl.ua/files/2020/Program_velo.pdf

4. NACTO Urban Bikeway Design Guide [Digital source] / National Association of City Transportation Officials. Access: https://nacto.org/publication/urban-bikewaydesign-guide (date of application 15.11.2021)

5. PRESTO Cycling Policy Guide-General Framewo [Digital source]. Access: https://presto-cycling.eu (date of application 15.11.2021)

6. Rekomendatsii $\mathrm{z}$ orhanizatsii rukhu velosypednoho transportu ERA / [pid kerivnytstvom Piu Hviazda, T. Brakhera]. - Keln: FGSV, 2010. - 105 p.

7. Lissner, S. Cycling Data App Data - An Exploratory Data Analysis of GPS Data in Cycling / S. Lissner, A. Francke, O. Chernyshova, T. Becker. // International Transportation (69) - 2017. - no. 1 - P. 48 - 52.

8. Lytvynenko T. P. Pryiomy orhanizatsii infrastruktury dlia rukhu indyvidualnykh ekolohichnykh transportnykh zasobiv / T. P. Lytvynenko, L. V. Hasenko // Naukovotekhnichnyi zbirnyk «Enerhoefektyvnist $\mathrm{v}$ budivnytstvi ta arkhitekturi». - K.: KNUBA, 2015. - Vypusk 7. - P. $155-160$.

9. Shchurova V. A. Udoskonalennia landshaftno-rekreatsiinoho seredovyshcha 
mist ta pozamiskykh terytorii shliakhom vprovadzhennia velosypednoi infrastruktury / V. A. Shchurova, M.V. Harbar // WORLD SCIENCE. № 10(38), Vol.1, October 2018, P. $15-21$.

10. Buravchenko S. H. Velosypedni trasy $\mathrm{v}$ rekreatsinykh zonakh yak zahalnomiski zviazky / S.H. Buravchenko, Tonkonoh D.Ie. // Teoriia i praktyka dyzainu. Dyzain arkhitekturnoho seredovyshcha. - K.: NAU, 2019. - Vypusk 7. - P. 7 - 15.

11. Bybyk V. I. Dyzain arkhitekturno-landshaftnoho prostoru velosypednykh komunikatsii / V. I. Bybyk, L. S. Shevchenko // Arkhitekturnyi visnyk KNUBA: nauk.vyrob. zb. / KNUBA; vidp. red. P. M. Kulikov. - Kyiv: KNUBA, 2017. - Vyp. 11-12. - P. $22-28$.

\section{Список використаної літератури}

1. ДБН В.2.3.-5:2018 Вулиці та дороги населених пунктів. К.: Міністерство регіонального розвитку, будівництва та житлово-комунального господарства України., 2018. $61 \mathrm{c.}$

2. ДБН Б.2.2-12:2018 Планування і забудова територій. К.: Мінрегіон України, 2018. $187 \mathrm{c}$.

3. Про затвердження Концепції розвитку велосипедної інфраструктури міста Полтава на 2020-2024 роки: Рішення Полтавської міської ради від 10.07.2020 [Електронний ресурс] / Офіційний сайт інституту розвитку міст. https://irm.pl.ua/files/2020/Program_velo.pdf

4. NACTO Urban Bikeway Design Guide [Електронний pecypc] / National Association of City Transportation Officials. Режим доступу: https://nacto.org/publication/urban-bikeway-design-guide (дата звернення 15.11.2021)

5. PRESTO Cycling Policy Guide-General Framewo [Електронний ресурс]. Режим доступу: https://presto-cycling.eu (дата звернення 15.11.2021)

6. Рекомендації з організації руху велосипедного транспорту ERA / [під керівництвом Пю Гвязда, Т. Брахера]. - Кельн: FGSV, 2010. - 105 р.

7. Lissner, S. Cycling Data App Data - An Exploratory Data Analysis of GPS Data in Cycling / S. Lissner, A. Francke, O. Chernyshova, T. Becker. // International Transportation (69) - 2017. - no. 1 - P. 48-52.

8. Литвиненко Т. П. Прийоми організації інфраструктури для руху індивідуальних екологічних транспортних засобів / Т. П. Литвиненко, Л. В. Гасенко // Науково-технічний збірник «Енергоефективність в будівництві та архітектурі». - К.: КНУБА, 2015. - Випуск 7. - С. $155-160$.

9. Щурова В. А. Удосконалення ландшафтно-рекреаційного середовища міст та позаміських територій шляхом впровадження велосипедної інфраструктури / В. А. Щурова, М.В. Гарбар // WORLD SCIENCE. № 10(38), Vol.1, October 2018, 15-21.

10. Буравченко С. Г. Велосипедні траси в рекреаційних зонах як загальноміські зв'язки / С.Г. Буравченко, Тонконог Д.С. // Теорія і практика дизайну. Дизайн архітектурного середовища. - К.: НАУ, 2019. - Випуск 7. - С. 7 15.

11. Бибик В. І. Дизайн архітектурно-ландшафтного простору велосипедних комунікацій / В. І. Бибик, Л. С. Шевченко // Архітектурний вісник КНУБА: наук.вироб. зб. / КНУБА; відп. ред. П. М. Куліков. - Київ: КНУБА, 2017. - Вип. 11-12. C. 22-28. 